\title{
The use of digital media for marketing, CSR communication and stakeholder engagement
}

\author{
By Ciro Troise ${ }^{1}$ and Mark Anthony Camilleri ${ }^{2}$
}

This is a prepublication version.

Suggested Citation: Troise, C., \& Camilleri, M. A. (2021). The use of the digital media for marketing, CSR communication and stakeholder engagement. In M. A. Camilleri (Ed.), Strategic corporate communication in the digital age. Bingley: Emerald, pp. 161-174. DOI: 10.1108/978-1-80071-264520211010

\begin{abstract}
The latest advances in digital technologies have changed the way companies communicate with their stakeholders. This chapter explores the businesses' usage of digital communication channels. It focuses on their utilization of social media for marketing and promotion of products, corporate social responsibility (CSR) practices and stakeholder engagement with financial stakeholders. An exploratory study was carried out on a sample of 167 Italian businesses. It investigated the companies' websites and their social media accounts. The findings suggest that the Italian businesses are using various social media networks for corporate communication purposes. This descriptive research shows that they are utilizing Facebook, LinkedIn and YouTube, among others, to communicate commercial information and to promote their business. Moreover, they are using Instagram and Twitter to raise awareness about their CSR initiatives. In conclusion, this chapter implies that marketers need to carefully coordinate the use of different digital tools to ensure that they reach their target audiences in an effective manner.
\end{abstract}

Keywords: Corporate Communication; Strategies; Stakeholders; Social Media; CSR; Marketing Tools; Crowdfunding.

\footnotetext{
${ }^{1}$ Knowledge Transfer Office, Università degli Studi della Campania Luigi Vanvitelli, Caserta, Italy. Email: ciro.troise@unicampania.it

${ }^{2}$ Department of Corporate Communication, Faculty of Media and Knowledge Sciences, University of Malta, Malta. Email: mark.a.camilleri@um.edu.mt
} 


\section{Introduction}

Digital entrepreneurial ecosystems have become a significant research agenda for both practitioners and scholars (Sussan \& Acs, 2016; Dini, Iqani \& Mansell, 2011; Li, Badr \& Biennier, 2012). A digital ecosystem is defined as a "self-organising, scalable and sustainable system composed of heterogeneous, digital entities and interrelations focusing on interactions among entities, to increase system utility, gain benefits, and promote information sharing, inner and inter cooperation and system innovation" ( $\mathrm{Li}$ et al., 2012: 119). The ecosystem of multisided platforms, including data-driven technologies can facilitate digital communications (Liu, Chen \& Chou, 2011; Berman, 2012; Westerman, Bonnet \& McAfee, 2014; Matt, Hess \& Benlian, 2015; Hess, Matt, Benlian \& Wiesböck, 2016; Troise, Matricano \& Sorrentino, 2020a) and their diffusion can support many types of companies in their marketing strategies and operations (Badescu \& Garcés-Ayerbe, 2009; Fitzgerald, Kruschwitz, Bonnet \& Welch, 2014; Trabucchi, Buganza \& Pellizzoni, 2017). This argumentation is synonymous with the so-called "Industry 4.0" paradigm. This notion is increasingly being used to describe the digitization of technologies and networks that are connected with one another (Lasi, Fettke, Kemper, Feld \& Hoffmann, 2014; Lee, Bagheri \& Kao, 2015; Gilchrist, 2016; Müller, Buliga \& Voigt, 2018; Ustundag \& Cevikcan, 2018; Sassi \& Goaied, 2013; De Waal et al., 2017).

These advances in technology have had important effects on the economy of many countries. The spread and development of online technologies are influencing the dynamics and outcomes of both traditional companies and new ventures (e.g. start-ups). This has led to the proliferation of new types of entrepreneurship, the so-called "digital entrepreneurship" that relies on online technologies including corporate websites, social media, review sites, et cetera (Nambisan, 2017; Srinivasan \& Venkatraman, 2018; Kraus, Palmer, Kailer, Kallinger \& Spitzer, 2019). These innovations enable large corporations as well as small and medium sized enterprises (SMEs) to use new business models to create value for themselves and their 
stakeholders (Mustafa, 2015; Zhong \& Nieminen, 2015). They also allow them to promote their products and services, and to engage in online conversations with prospective customers (Camilleri, 2018a).

\subsection{Research Question}

Companies adopt specific strategies and use marketing channels to communicate with different types of stakeholders. The stakeholders speak their own language, they may prefer particular channels, over others. In the digital scenario, companies can use various digital media to reach out to specific target audiences. In this light, this chapter investigates the rationale for using the digital media for marketing purposes and for corporate communications with stakeholders.

This contribution analyzes digital communication channels that are increasingly being used by Italian companies to engage with their stakeholders. It explores how businesses are conveying their promotional information and signals about products (or services), commercial information, and CSR communications through websites and social networks to influence prospective customers. It clarifies that their CSR communications may be targeted at different stakeholders, thus the companies may use certain channels for their corporate disclosures.

\section{Background}

Many online users have subscribed to different social media networks, for different reasons. Individuals and groups use them to publish their ideas in writing, images or videos. They also enable them to share hyperlinks to articles, pictures and videos. There are social media users who like to follow the updates of their friends, colleagues, acquaintances, influential individuals, virtual communities and/or organizations. They may do so to connect 
with other individuals who shared their interests and values. The posts on social networks can be disseminated in a viral manner through the social media users' likes or shares. Many online users have subscribed to different social media, including Facebook, YouTube, Instagram, Twitter and LinkedIn, among others for different reasons.

Currently, Facebook has 2.45 billion users. Other popular social media networks include Instagram (1 billion users), Reddit (430 million users), Snapchat (360 million users), Twitter (330 million users), Pinterest (322 million users) and LinkedIn (310 million users) (SEJ, 2020). Different businesses are increasingly creating interactive pages and groups to disseminate information about their products and services (Leonardi \& Vaast, 2017; Bird, Schjoedt \& Baum, 2012) and to engage in online conversations with their followers (Camilleri, 2018a). They utilize Facebook Messenger, or live video broadcasts to enhance their communications.

Like Facebook, other social media, including Twitter can be used to target large audiences and communities. Twitter is a platform that is based on topical content. Generally, its users are encouraged to use keywords and hashtags on particular topics, in particular locations. Twitter is restricted with a 280-character limit. Therefore, its subscribers have to post short, focused messages with relevant content that appeals to their followers (Camilleri, 2020). They are expected to dedicate time to look after their account as they need to respond to their followers to avoid negative criticism. Both Facebook and Twitter allow direct, two-way communications among subscribers. Hence, they can be used to engage in interactive conversations with other users.

Other digital networks include Instagram, Snapchat and Pinterest. Instagram and Pinterest are focused on the dissemination of images and visual content. Instagram and Snapchat can also feature videos and user-generated content. Hence, they may include 
influencer marketing material. On the other hand, Reddit appeals to particular communities and niches, who share similar interests on various topics (Camilleri, 2020; SEJ, 2020).

The usage of social media has radically influenced the style of communication and the dissemination of knowledge and information. Platforms can be personalized, self-managed and interconnected as they can blend written content with images, videos and hyperlinks. This disruptive innovation has led individuals from different demographic segments in society, to refine their digital and communication skills. It is obvious that social media has impacted our way of thinking, talking and even our social lives.

One of the main challenges for academia as well as for practitioners is to predict the evolutionary patterns in the digital transformation era (Majchrzak, Markus \& Wareham, 2016), in particular for high-tech industries (Powers \& Wilson, 2010; Manral, 2011). There are several factors that can influence the strategic decision-making processes (Elbanna, Thanos \& Papadakis, 2014). For example, different networks provide access to national and international markets as well as to diverse corporate innovation communities (Kilubi, 2016; Clauss \& Spieth, 2017; Roth, Dumbach, Schliffka \& Möslein, 2017). The advances in technology are changing the corporate communications. The digital technologies play a central role to the expansion of electronic content across different platforms. They offer several challenges and opportunities for many companies.

The development of new technologies, including social media and review sites, allow companies to improve their performance and to enhance their communications (Westerman et al., 2014). These innovations have an effect on the communications' choices of companies or entrepreneurs and their strategic decision-making processes (Cohen, Amorós \& Lundyd, 2017; Aydalot \& Keeble, 2018; Li, Su, Zhang \& Mao, 2018). In this evolving scenario, there are several innovative technologies that can have a disruptive impact on today's corporate 
communication processes. These may include: artificial intelligence (AI), machine learning (ML), internet of things (IoT), big data analytics, mobile applications, cloud computing, augmented and virtual reality, blockchain, and other financial technologies (Fintech) such as initial coin offering (ICO) and crowdfunding technologies, among others.

The business owner-managers or their chief information officers (CIOs), chief marketing officers (CMOs), chief communication officers (CCOs) may face difficulties and risks in managing the opportunities associated with the new challenges of digital transformation (Hess et al., 2016). Their main goal is to achieve a competitive advantage by improve their corporate image and reputation through their digital presence (Andriole, 2017). Indeed, new digital technologies can help firms to interact with online users (Berman, 2012; Matt et al., 2015) or to leverage their image and reputation among several types of stakeholders (in particular customers, suppliers, investors, other companies, employees, investors, social communities, non-governmental organizations, public agencies or authorities (Camilleri, 2018b; Van Riel \& Fombrun, 2007). The companies' organizational goals and their corporate communications ought to be in line with their stakeholders' expectations and interests (Camilleri, 2015; Gardberg \& Fombrun, 2006).

\section{Corporate Communication}

Steyn (2003) contended that corporate communication is a functional task as it links key strategic issues facing organizations and their communication plans. In fact, the corporate communication strategy is a significant outcome of an organization's strategic thinking process. Businesses may use formal corporate communications to disseminate information about their strategies, operations, courses of action and organizational performance with relevant stakeholders. Van Riel and Fombrun's (2007) book define corporate communication as a network of people who communicate with each other. In their own words, "In all 
organizations, communications flow vertically and horizontally, internally and externally, formally and informally, linking employees internally to each other, to various layers of management, and to the many external resource-holders of the organization" (p. 13). Arguably, not all organizational communications may be related to work practices. Hence, they may not always satisfy the organizational objectives. However, there may be certain organizational communications that can influence, to some extent, the perceptions of participants and observers about the organization and its activities. Thus, they can affect the organization's corporate identity, image and reputation (Cornelissen, 2017).

Various researchers distinguished between external and internal corporate communications. For instance, external corporate communication is clearly evidenced in advertising, branding exercises, public relations, crises communications, et cetera, whilst, internal corporate communications are conspicuous with industrial relations, issues management, et cetera (Schultz \& Kitchen, 2004; Johansen, Johansen \& Weckesser, 2016; Balmer, 2017). Van Riel \& Fombrun (2007) suggested that there are three principal clusters of task-related communication activities within organizations, namely: (i) management communications, (ii) marketing communications, and (iii) organizational communications. Firstly, the management communications are communications that are intended to lead and control organizations. Therefore, management communications involve communications between managers as well as with other employees within an organization. This form of communication is often described as a top-down approach or downward communication as it is used by the top-level management to communicate to the lower levels about policies, code of practice, guidelines, et cetera. Organizational leaders may use the following media for their management communications: written memoranda emails, social networks other than the company's Intranet or blog, face-to-face or virtual meetings, internal blogs, printed newsletters, electronic newsletters, webcasts and videos (live or on-demand), et cetera. 
Secondly, the marketing communications is related to promotional communication messages, including advertising and promotions through different media. Therefore, this form of communication is used to promote the business and its products or services. Its underlying objectives may include to increase sales and brand equity, among others (Camilleri, 2017a). Thirdly, the organizational communications involve informal as well as formal communications in organizations. The informal communication is associated with interpersonal, horizontal communications among employees. Such communications, including gossip, rumours, et cetera, are often referred to as grapevine, as messages spread among members of staff within an organization. The formal communications may include public communications with stakeholders, including the government, media, investors, customers and the general public, among others. For instance, CCI (2019) indicated that various businesses are dedicating an investor relations website or designated section within their public site.

The latest technological developments have transformed the corporate communication landscape and have led to significant changes in the industry. Hence, the communication professionals need to possess adequate digital and language skills to prepare and disseminate relevant content online. They can use digital media channels, including emails, corporate websites, blogs and social media. In this day and age, they are expected to engage with social media users in Facebook, Instagram, LinkedIn, Twitter, YouTube, among others, and to respond to them in a timely manner. This way, they will be in a position to amplify their messages. CCI (2019) suggested that the email is the most effective medium that is being used in organizational communication. This is closely followed by the intranet and face-to-face meetings. Table 1 features contemporary approaches that organizational leaders use to engage with their employees. 


\section{Insert Table 1 here}

The companies are utilizing several digital media channels for their external communications, as shown in Table 2. CCI (2019) reported that the website remains the most popular channel for corporate communication (95.1\%). This is followed by Facebook and Twitter $(87.8 \%)$ and by LinkedIn and YouTube (75.6\%).

\section{Insert Table 2 here}

Various social media have become key elements for the businesses' corporate communications and stakeholder engagement. A growing number of entrepreneurs and managers are increasingly using the social media for their marketing and communications (e.g. Fischer \& Reuber, 2011; Mumi, Obal \& Yang, 2019). Kietzmann, Hermkens, Mccarthy and Silvestre (2011) among others, investigated the "social media phenomenon" and its significant impact on the firms' reputation, sales and survival. Kietzmann et al. (2011) proposed a specific framework that they considered as the functional building blocks of social media. They explained that firms are expected to manage their identity, conversations, shared content, presence, relationships, reputation, and groups when they engage with social media users. The authors contended that different social media activities are defined by the extent to which they focus on some or all of these blocks. 


\section{Data collection and analysis}

This exploratory research focuses on three aspects of corporate communication, including marketing, CSR communication and the dissemination of commercial information for stakeholders. Descriptive data was collected through a purposive sample of 167 Italian companies. The researchers have captured and analyzed the businesses' online content from their corporate websites and social media pages. They identified the digital communication channels that they were using for the marketing of products and services and to promote CSR behaviors and/or fundraising activities.

\subsection{Marketing}

The extant literature is rich in theoretical and empirical studies that examine the use of social media for the marketing and promotions of products (Munger \& Grewal, 2001; Chu \& Kim, 2011; Kim \& Ko, 2012; Sashi, 2012; Singh \& Sonnenburg, 2012; Smith, Fischer \& Yongjian, 2012; Trainor, Andzulis, Rapp \& Agnihotri, 2014 Braojos-Gomes, Benitez-Amado \& Llorens-Montes, 2015; Mills \& Plangger, 2015; Agnihotri, Dingus, Hu \& Krush, 2016). 2016; Godey, Manthiou, Pederzoli, Rokka, Aiello, Donvito \& Singhd, 2016; Schivinski \& Dabrowski, 2016; Felix, Rauschnabel \& Hinsch, 2017). In this vein, social media is a useful tool for businesses to enhance their marketing objectives (Trusov, Bucklin \& Pauwels, 2009; Dholakia \& Durham, 2010; Kozinets, de Valck, Wojnicki \& Wilner, 2010). In fact, the findings from this exploratory research suggest that the majority of the Italian companies are using Facebook (92\%), YouTube (91\%) Twitter (89\%), Instagram (86\%), LinkedIn (85\%) and Pinterest (49\%) to market their products and services. 


\subsection{Corporate social responsibility communication}

The digital media are also used to communicate about the businesses' CSR initiatives (Du \& Viera, 2012; Colleoni, 2013; Etter, 2013; Dutot, Lacalle Galvez \& Versailles, 2016; Camilleri, 2018a; 2017b). Morsing (2006) suggested that managers should communicate about their CSR behaviors if they want to improve their legitimacy and reputation among stakeholders. Similarly, Eberle, Berens and Li (2013) also recommended that companies ought to communicate about their CSR activities through interactive, online media. The scholars investigated the effects deriving from social media usage on the companies' reputation.

Their findings indicated that an increase in perceived interactivity leads to higher message credibility and stronger feelings of identification with the company, that translated to an improved corporate reputation and positive Word of Mouth (WoM) publicity. This result implies that the promotion of CSR communications through interactive channels can improve the corporate reputation of the businesses. In this case, most of the Italian companies (about $76 \%$ of them) were communicating about their CSR efforts to their stakeholders, including the regulatory authorities, investors, customers, et cetera, through ad hoc reports. In fact, they were publishing their annual CSR reports (in Italian "bilancio sociale") in their websites. Some companies also promoted them through the digital media.

\subsection{Stakeholder engagement}

The organizations' communications through the digital media can have positive effects on the companies' relationships with marketplace stakeholders including investors and financial institutions (Luo, Zhang \& Duan, 2013; Yu, Duan \& Cao, 2013; Paniagua \& Sapena, 2014). Schniederjans et al. (2013) showed that social media enhances the companies' financial performance and has a positive effect on impression management. Furthermore, other scholars found that social media reinforces the companies' relationships with several stakeholders. For 
example, Mumi et al. (2019) indicated that there is a positive correlation between the companies' usage of social media and the initial public offering (IPO) value, thus confirming the signaling role of social media.

The social media communications can also have a positive effect on the businesses' likelihood to attract finance from prospective investors and/or through crowdfunding (Mollick, 2014; Zheng, Li, Wu \& Xu, 2014; Lukkarinen, Teich, Wallenius \& Wallenius, 2016; Vismara, 2016; Polzin, Toxopeus \& Stam, 2018; Troise, 2020; Troise \& Tani, 2020; Troise, Matricano, Candelo \& Sorrentino, 2020b). The social media can link entrepreneurs with potential investors and may even reduce information asymmetries between them (Shane \& Cable 2002). The social media networks can help to raise awareness about financial services. In fact, online users may come across social media posts that are promoting investments and crowdfunding opportunities. Several studies have indicated that social media is positively related to crowdfunding success in terms of reward crowdfunding (Mollick, 2014; Colombo, Franzoni \& Rossi Lamastra, 2015), donation crowdfunding (Ordanini, Miceli, Pizzetti \& Parasuraman, 2011) and equity crowdfunding (Lukkarinen et al., 2016; Vismara, 2016).

Social media enable prospective investors to connect with financial service providers. Potential investors can follow the corporate communications of banks, and other financial service businesses and learn about their new products, services and/or CSR communications. The companies can leverage themselves through the social media communications and can even influence their investors' decision-making processes (Mollick, 2014; Colombo et al., 2015). Companies as well as entrepreneurs are increasingly using the social networks as signaling media to access finance (e.g. via crowdfunding) (Vismara 2016). In this light, this exploratory study found that the Italian companies were using Facebook (91\%), LinkedIn $(87 \%)$ and YouTube (77\%) to disseminate commercial information about their company. This information was targeted at venture capitalists, business angels and crowd funders. These 
findings also suggest that Instagram and Twitter were less popular media for this purpose (in the Italian context).

\section{Conclusion}

This chapter builds on the extant literature on corporate communication in the digital era. It explained how different digital media, including corporate web sites and social networks are increasingly being used for the marketing of products, and for CSR communications and stakeholder engagement. This contribution has presented the descriptive findings from an exploratory study on the Italian corporations' usage of digital media for corporate communication. The researchers clarified that there are a number of online channels that can be used by corporate managers to convey commercial information and CSR communications to stakeholders. They argue that there is scope for businesses to embrace the dynamics of the digital media to improve the effectiveness of their communications activities. Thus, managers ought to manage their communication strategies and adapt them to their stakeholders. They should pay high attention to choose the most appropriate media, and to create relevant corporate communications content that meets and exceeds their stakeholders' expectations, in order to increase their corporate identity, image and reputation.

This contribution puts forward theoretical as well as practical implications for practitioners. Firstly, it clarified that the digital media are important tools for corporate communications. Hence, they can be used for several purposes, including for the promotion of products, and to disseminate commercial information and CSR communications among stakeholders. Secondly, it enriches our understanding of digital corporate communications. From the managerial perspective, this research sheds light on a set of digital marketing tools for business practitioners. This study reported that social media can be used to raise awareness 
about the organizations' CSR activities and to promote financial investments and crowdfunding initiatives.

From a theoretical perspective, it is hoped that this research will lead to further studies that will examine the use of digital media for corporate communication. Prospective researchers may use different sampling frames and methodologies to investigate this topic in more depth and breadth. They can investigate the stakeholders' or consumers' perceptions and attitudes toward corporate communications relating to commercial and/or CSR information of specific companies. Further research in this field might delve deeper into multiple signals deriving from different digital communication channels, including websites or social media messages. Empirical studies should be carried out different contexts, and may include different businesses, including SMEs and startups.

\section{Acknowledgements}

The authors thank the reviewers for their critical remarks and suggestions.

\section{References}

Agnihotri, R., Dingus, R., Hu, M.Y. \& Krush, M.T. (2016). Social media: influencing customer satisfaction in B2B sales. Industrial Marketing Management, 53, 172-180.

Andriole, S.J. (2017). Five myths about digital transformation. MIT Sloan Management Review, 58(3), 20-22.

Aydalot, P. \& Keeble, D. (2018). High technology industry and innovative environments: the European experience, Routledge, Oxford, UK.

Badescu, M. \& Garcés-Ayerbe, C. (2009). The impact of information technologies on firm productivity: Empirical evidence from Spain. Technovation, 29(2), 122-129.

Balmer, J. M. (2017). The corporate identity, total corporate communications, stakeholders' attributed identities, identifications and behaviors continuum. European Journal of Marketing, 51(9-10), 1472-1502.

Berman, S. (2012). Digital transformation: opportunities to create new business models. Strategy and Leadership, 40(2), 16-24. 
Bird, B.J., Schjoedt, L. \& Baum, J.R. (2012). Entrepreneurs' behavior: elucidation andmeasurement. Entrepreneurship Theory and Practice, 36(5), 889-913.

Braojos-Gomes, J., Benitez-Amado, J. \& Llorens-Montes, F. (2015). How do small firms learn to develop a social media competence? International Journal of Information Management, 35(4), 443-458.

Camilleri, M.A. (2015). Valuing Stakeholder Engagement and Sustainability Reporting. Corporate Reputation Review, 18(3), 210-222.

Camilleri, M. A. (2017a). The promotion of responsible tourism management through digital media. Tourism Planning and Development, 15(6), 653-671.

Camilleri, M.A. (2017b). Corporate Sustainability, Social Responsibility and Environmental Management: An Introduction to Theory and Practice with Case Studies, Cham, Switzerland: Springer Nature.

Camilleri, M. A. (2018a). The SMEs' technology acceptance of digital media for stakeholder engagement. Journal of Small Business and Enterprise Development, 26(4), 504-521.

Camilleri, M.A. (2018b). Theoretical Insights on Integrated Reporting: The Inclusion of NonFinancial Capitals in Corporate Disclosures. Corporate Communications: An International Journal, 23(4), 567-581.

Camilleri, M. A. (2020). The use of data-driven technologies for customer-centric marketing. International Journal of Big Data Management, 1(1), 50-63.

Chu, S.C. \& Kim, Y. (2011). Determinants of consumer engagement in electronic word-ofmouth (EWOM) in social networking sites. International Journal of Advertising, 30(1), 47 75 .

Clauss, T. \& Spieth, P. (2017). Governance of open innovation networks with national vs international scope. Journal of Strategy and Management, 10(1), 66-85.

Cohen, B., Amorós, J.E. \& Lundyd, L. (2017). The generative potential of emerging technology to support startups and new ecosystems. Business Horizon, 60(6), 741-745.

Colombo, M.G., Franzoni, C. \& Rossi Lamastra, C. (2015). Internal social capital and the attraction of early contributionsin crowdfunding. Entrepreneurship Theory and Practice, 39(1), 75-100.

Colleoni, E. (2013). CSR communication strategies for organizational legitimacy in social media. Corporate Communications: An International Journal, 18(2), 228-248.

Cornelissen, J.P. (2008). Corporate Communication. The International Encyclopedia of Communication, https://onlinelibrary.wiley.com/doi/abs/10.1002/9781405186407.wbiecc143

CCI (2019). CCI Corporate Communication Practices and Trends Study 2019 Final Report. https://corporatecomm.org/wp-content/uploads/2019/10/CCI-Practices-and-Trends-Study2019-Final-Report-October-2019-1.pdf

De Waal, A., Habil, D. \& Goedegebuure, R. (2017). Formulating a partnership framework for Egyptian ICT companies. Journal of Strategy and Management, 10(3), 293-312. 
Dholakia, U.M. \& Durham, E. (2010). One café chain's Facebook experiment. Harvard Business Review, 88(3), 1-26.

Dini, P., Iqani, M. \& Mansell, R. (2011). The (im) possibility of interdisciplinary lessons from constructing a theoretical framework for digital ecosystems. Culture, Theory and Critique, 52(1), 3-27.

Du, S. Vieira, E.T. (2012). Striving for Legitimacy Through Corporate Social Responsibility: Insights from Oil Companies. Journal of Business Ethics, 110, 413-427.

Dutot, V., Lacalle Galvez, E. \& Versailles, D. (2016). CSR communications strategies through social media and influence on e-reputation: An exploratory study. Management Decision, 54(2), 363-389.

Eberle, D., Berens, G. \& Li, T. (2013). The Impact of Interactive Corporate Social Responsibility Communication on Corporate Reputation. Journal of Business Ethics, 118, 731-746.

Elbanna, S., Thanos, C.I. \& Papadakis, M.V. (2014). Understanding how the contextual variables influence political behavior in strategic decision-making. Journal of Strategy and Management, 7(3), 226-250.

Etter, M. (2013). Reasons for low levels of interactivity: (Non-) interactive CSR communication in twitter. Public Relations Review, 39(5), 606-608.

Felix, R., Rauschnabel, P.A. \& Hinsch, C. (2017). Elements of strategic social media marketing: A holistic framework. Journal of Business Research, 70, 118-126.

Fischer, E. \& Reuber, A.R. (2011). Social interaction via new social media: (How) can interactions on Twitter affect effectual thinking and behavior? Journal of Business Venturing, 26(1), 1-18.

Fitzgerald, M., Kruschwitz, N., Bonnet, D. \& Welch, M. (2014). Embracing digital technology: A new strategic imperative. MIT Sloan Management Review, 55(2), 1-12.

Gardberg, N.A. \& Fombrun, C. J. (2006). Corporate Citizenship: Creating Intangible Assets across Institutional Environments. Academy of Management Review, 31(2), 329-346.

Gilchrist, A. (2016). Industry 4.0, Apress, Berkeley, CA, USA.

Godey, B., Manthiou, A., Pederzoli, D., Rokka, J., Aiello, G., Donvito, R. \& Singhd, R. (2016). Social media marketing efforts of luxury brands: Influence on brand equity and consumer behavior. Journal of Business Research, 69(12), 5833-5841.

Hess, T., Matt, C., Benlian, A. \& Wiesböck, F. (2016). Options for Formulating a Digital Transformation Strategy. MIS Quarterly Executive, 15(2), 123-139.

Johansen, B. F., Johansen, W. \& Weckesser, N. M. (2016). Emotional stakeholders as "crisis communicators" in social media. Corporate Communications: An International Journal, 21(3), 289-308.

Kietzmann, J.H., Hermkens, K., Mccarthy, I.P. \& Silvestre, B.S. (2011). Social media? Get serious! Understanding the functional building blocks of social media. Business Horizons, 54(3), 241-251. 
Kilubi, I. (2016). Strategic technology partnering capabilities. Journal of Strategy and Management, 9(2), 216-255.

Kim, A.J. \& Ko, E. (2012). Do social media marketing activities enhance customer equity? An empirical study of luxury fashion brand. Journal of Business Research, 65(10), 14801486.

Kozinets, R., de Valck, C., Wojnicki, A. \& Wilner, S. (2010). Networked narratives: understanding word-of-mouth marketing in online communities. Journal of Marketing, 74(2), 71-89.

Kraus, S., Palmer, C., Kailer, N., Kallinger, F. \& Spitzer, J. (2019). Digital entrepreneurship. International Journal of Entrepreneurial Behavior and Research, 25(2), 353-375.

Lasi, H., Fettke, P., Kemper, H.G., Feld, T. \& Hoffmann, M. (2014). Industry 4.0. Business and Information Systems Engineering, 6(4), 261-264.

Lee, J., Bagheri, B. \& Kao, H.A. (2015). A Cyber-Physical Systems architecture for Industry 4.0-based manufacturing systems. Manufacturing Letters, 3, 18-23.

Leonardi, P. \& Vaast, E. (2017). Social media and their affordances for organizing: A review and agenda for research. Academy of Management Annals, 11, 150-188.

Li, W., Badr, Y. \& Biennier, F. (2012). Digital ecosystems: challengesand prospects. In proceedings of the International Conference on Management of Emergent Digital Eco Systems, 117-122. ACM.

Li, L., Su, F., Zhang, W. \& Mao, J.Y. (2018). Digital transformation by SME entrepreneurs: A capability perspective. Information Systems Journal, 28(6), 1129-1157.

Liu, D., Chen, S. \& Chou, T. (2011). Resource fit in digital transformation: Lessons learned from the CBC Bank global e-banking project. Management Decision, 49(10), 1728-1742.

Lukkarinen, A., Teich, J.E, Wallenius, H. \& Wallenius, J. (2016). Success Drivers of Online Equity Crowdfunding Campaigns. Decision Support Systems, 87(C), 26-38.

Luo, X., Zhang, J. \& Duan, W. (2013). Social media and firm equity value. Information Systems Research, 24(1), 146-163.

Majchrzak, A., Markus, M.L. \& Wareham, J. (2016). Designing for digital transformation: Lessons for information systems research from the study of ICT and societal challenges. MIS Quarterly, 40(2), 267-277.

Manral, L. (2011). Evolution of industries based on systemic technologies. Journal of Strategy and Management, 4(4), 384-403.

Matt, C., Hess, T. and Benlian, A. (2015). Digital Transformation Strategies. Business and Information Systems Engineering, 57(5), 339-343.

Mills, A.J. \& Plangger, K. (2015). Social media strategy for online service brands. Service Industries Journal, 35(10), 521-536.

Mollick, E. (2014). The dynamics of crowdfunding: An exploratory study. Journal of Business Venturing, 29(1), 1-16. 
Morsing, M. (2006). Corporate social responsibility as strategic auto-communication: on the role of external stakeholders for member identification. Business Ethics: A European Review, $15(2), 171-182$.

Müller, J.M., Buliga, O. \& Voigt, K.I. (2018). Fortune favors the prepared: How SMEs approach business model innovations in Industry 4.0. Technological Forecasting and Social Change, 132, 2-17.

Mumi, A., Obal, M. \& Yang, Y. (2019). Investigating social media as a firm's signaling strategy through an IPO. Small Business Economics, 53(3), 631-645.

Munger, J.L. \& Grewal, D. (2001). The effects of alternative price promotional methods on consumers' product evaluations and purchase intentions. Journal of Product and Brand Management, 10(3), 185-197.

Mustafa, R. (2015). Business model innovation. Journal of Strategy and Management, 8(4), 342-367.

Nambisan, S. (2017). Digital entrepreneurship: Toward a digital technology perspective of entrepreneurship. Entrepreneurship Theory and Practice, 41(6), 1029-1055.

Ordanini, A., Miceli, L., Pizzetti, M. \& Parasuraman, A. (2011). Crowd-funding: Transforming customers into investorsthrough innovative service platforms. Journal of Service Management, 22(4), 443-470.

Paniagua, J. \& Sapena, J. (2014). Business performance and social media: love or hate? Business Horizons, 57(6), 719-728.

Polzin, F., Toxopeus, H. \& Stam, E. (2018). The wisdom of the crowd in funding. Information heterogeneity and social networks of crowdfunders. Small Business Economics, 50(2), 251-273.

Powers, T. \& Wilson, R. (2010). Management perspectives of high technology strategic alliance outcomes. Journal of Strategy and Management, 3(1), 4-19.

Roth, A., Dumbach, M., Schliffka, B. \& Möslein, K. (2017). Successful management of diverse corporate innovation communities. Journal of Strategy and Management, 10(1), 2-18.

Sashi, C. (2012). Customer engagement, buyer-seller relationships \& social media. Management Decision, 50(2), 253-272.

Sassi, S. \& Goaied, M. (2013). Financial development, ICT diffusion and economic growth: Lessons from MENA region. Telecommunications Policy, 37(4-5), 252-261.

Schivinski, B. \& Dabrowski, D. (2016). The effect of social media communication on consumer perceptions of brands. Journal of Marketing Communications, 22(2), 189-214.

Schniederjans, D., Cao, E.S. \& Schniederjans, M. (2013). Enhancing financial performance with social media: An impression management perspective. Decision Support Systems, 55(4), 911-918.

Schultz, D. E. \& Kitchen, P. J. (2004). Managing the changes in corporate branding and communication: Closing and re-opening the corporate umbrella. Corporate Reputation Review, 6(4), 347-366. 
SEJ (2020). The 7 Biggest Social Media Sites in 2020. Search Engine Journal. https://www.searchenginejournal.com/social-media/biggest-social-media-sites/\#close

Shane, S. \& Cable, D. (2002). Network ties, reputation, and the financing of new ventures. Management Science, 48(3), 364-381.

Singh, S. \& Sonnenburg, S. (2012). Brand performance in social media. Journal of Interactive Marketing, 26(4), 189-197.

Smith, A.N., Fischer, E. \& Yongjian, C. (2012). How does brand-related user-generated content differ across YouTube, Facebook, and Twitter? Journal of Interactive Marketing, 26(2), 102-113.

Srinivasan, A. \& Venkatraman, N. (2018). Entrepreneurship in digital platforms: A networkcentric view. Strategic Entrepreneurship Journal, 12(1), 54-71.

Steyn, B. (2003). From strategy to corporate communication strategy: A conceptualisation. Journal of Communication Management, 8(2), 168-183.

Sussan, F. \& Acs, Z.J. (2016). The Digital Entrepreneurial Ecosystem. Small Business Economics, 49(1), 55-73.

Trabucchi, D., Buganza, T. \& Pellizzoni, E. (2017). Give away your digital services: Leveraging big data to capture value. Research-Technology Management, 60(2), 43-52.

Trainor, K.J., Andzulis, J., Rapp, A. \& Agnihotri, R. (2014). Social media technology usage and customer relationship performance: A capabilities-based examination of social CRM. Journal of Business Research, 67(6), 1201-1208.

Troise, C. (2020). Discovering the underlying dynamics of crowdfunding networks: entrepreneurs' ties, crowdfunders' connections and community spin-offs. Journal of Enterprising Communities: People and Places in the Global Economy, 14(2), 277-298.

Troise, C. and Tani, M. (2020), "Exploring entrepreneurial characteristics, motivations and behaviors in equity crowdfunding: some evidence from Italy", Management Decision, aheadof-print No. ahead-of-print. https://doi.org/10.1108/MD-10-2019-1431.

Troise, C., Matricano, D. and Sorrentino, M. (2020a). Open Innovation Platforms: exploring the importance of knowledge in supporting online initiatives. Knowledge Management Research \& Practice, DOI: 10.1080/14778238.2020.1747368. https://www.tandfonline.com/doi/abs/10.1080/14778238.2020.1747368

Troise, C., Matricano, D., Candelo, E. and Sorrentino, M. (2020b). Crowdfunded and then? The role of Intellectual Capital in the growth of equity-crowdfunded companies. Measuring Business Excellence. DOI:10.1108/MBE-02-2020-0031. https://www.emerald.com/insight/content/doi/10.1108/MD-10-2019-1431/full/html

Trusov, M., Bucklin, R. \& Pauwels, K. (2009). Effects of word-of-mouth versus traditional marketing: findings from an internet social networking site. Journal of Marketing, 73(5), 90102.

Ustundag, A. \& Cevikcan, E. (2018). Industry 4.0: Managing the digital transformation, Springer International Publishing, Cham, Switzerland, 
Van Riel, C.B.M. \& Fombrun, C.J. (2007). Essentials of Corporate Communication: Implementing Practices for Effective Reputation Management. Oxford, UK: Routledge, 1306.

Vismara, S. (2016). Equity retention and social network theory in equity crowdfunding. Small Business Economics, 46(4), 579-590.

Westerman, G., Bonnet, D. \& McAfee, A. (2014). The Nine Elements of Digital Transformation. MIT Sloan Management Review, 55(3), 1-6.

Yu, Y., Duan, W. \& Cao, Q. (2013). The impact of social and conventional media on firm equity value: A sentiment analysis approach. Decision Support Systems, 55(4), 919-926.

Zheng, H., Li, D., Wu, J. \& Xu, Y. (2014). The role of multidimensional social capital in crowdfunding: a comparative study in China and US. Information and Management, 51(4), 488-496.

Zhong, J. \& Nieminen, M. (2015). Resource-based co-innovation through platform ecosystem: experiences of mobile payment innovation in China. Journal of Strategy and Management, 8(3), 283-298. 